\title{
Development of a Bioengineered Skin-Humanized Mouse Model for Psoriasis
}

\section{Dissecting Epidermal-Lymphocyte Interacting Pathways}

\author{
Sara Guerrero-Aspizua, ${ }^{*}$ Marta García, ${ }^{*}$ \\ Rodolfo Murillas, ${ }^{\dagger}$ Luisa Retamosa, ${ }^{*}$ Nuria Illera, ${ }^{*}$ \\ Blanca Duarte, ${ }^{\dagger}$ Almudena Holguín, ${ }^{\star}$ \\ Susana Puig, ${ }^{\ddagger}$ Maria Isabel Hernández, \\ Alvaro Meana, " Jose Luis Jorcano, ${ }^{\star \dagger}$ \\ Fernando Larcher, ${ }^{\dagger}$ Marta Carretero, ${ }^{\dagger}$ \\ and Marcela Del Río* \\ From the Regenerative Medicine Unit," and the Cutaneous \\ Diseases Modeling Unit, ${ }^{\dagger}$ Epithelial Biomedicine Division, Basic \\ Research Department, Centro de Investigaciones Energéticas, \\ Medioambientales y Tecnológicas (CIEMAT) and Centre for \\ Biomedical Research on Rare Diseases (CIBERER), Madrid; the \\ Dermatology Department, ${ }^{\ddagger}$ Hospital Clinic de Barcelona, \\ Barcelona; and the Centre for Biomedical Research on Rare \\ Diseases (CIBERER), Barcelona; Servicio de Dermatología, ${ }^{\$}$ \\ Hospital Básico de la Defensa, Valencia; the Tissue Engineering \\ Unit, ${ }^{\text {Tा }}$ Centro Comunitario de Sangre y Tejidos de Asturias, \\ Oviedo; and the Centre for Biomedical Research on Rare \\ Diseases (CIBERER), Oviedo, Spain
}

Over the past few years, whole skin xenotransplantation models that mimic different aspects of psoriasis have become available. However, these models are strongly constrained by the lack of skin donor availability and homogeneity. We present in this study a bioengineering-based skin-humanized mouse model for psoriasis, either in an autologous version using samples derived from psoriatic patients or, more importantly, in an allogeneic context, starting from skin biopsies and blood samples from unrelated healthy donors. After engraftment, the regenerated human skin presents the typical architecture of normal human skin but, in both cases, immunological reconstitution through intradermal injection in the regenerated skin using in vitro-differentiated $\mathrm{T} 1$ subpopulations as well as recombinant $\mathrm{IL}-17$ and $\mathrm{IL}-22$ Th17 cytokines, together with removal of the stratum corneum barrier by a mild abrasive treatment, leads to the rapid conversion of the skin into a bona fide psoriatic pheno- type. Major hallmarks of psoriasis were confirmed by the evaluation of specific epidermal differentiation and proliferation markers as well as the mesenchymal milieu, including angiogenesis and infiltrate. Our bioengineered skin-based system represents a robust platform to reliably assess the molecular and cellular mechanisms underlying the complex interdependence between epidermal cells and the immune system. The system may also prove suitable to assess preclinical studies that test the efficacy of novel therapeutic treatments and to predict individual patient response to therapy. (Am J Pathol 2010, 177:3112-3124; DOI: 10.2353/ajpath.2010.100078)

Psoriasis is a T cell-mediated inflammatory skin disorder, multifactorial in its etiology. It affects about $2 \%$ of the worldwide population. There is a wide range of clinical presentations of the disease, but the most common variety is the chronic plaque psoriasis. In many cases the severity of the outcome may have serious (disabling) physical as well as psychological consequences. ${ }^{1}$

Several transgenic and knockout mouse models of the disease have been developed to date, and they have been proved to be valuable tools to establish the contribution of specific molecules to the pathogenesis of the disease. ${ }^{2,3}$ However, none of them fully recapitulates the complex pathophysiology of human psoriasis. Moreover, human skin presents major differences with mouse skin, making it more difficult to mimic the human condition.

Supported in part by grants P-BIO-0306-2006 from Comunidad de Madrid, PSE-010000-2008-7 and grant SAF 2007-61019 (M.D.R.) from MICINN, MICINN: Ministerio de Ciencia e Innovación.

Accepted for publication August 13, 2010

Supplemental material for this article can be found on http://ajp. amjpathol.org

Address reprint requests to Dr. Marcela del Rio, Regenerative Medicine Unit, or Dr. Marta Carretero Cutaneous Diseases Modeling Unit, Epithelial Biomedicine Division, Basic Research Department, CIEMAT, Av. Complutense 22, Edificio 70A, 28040 Madrid, Spain. E-mail: marcela.delrio@ ciemat.es and marta.carretero@ciemat.es. 
Thus, humanized animal models appear as an attractive alternative to other genetically modified animal models and might be very useful as a platform to test novel drug compounds to treat this disease. Some efforts have been made in this direction, and the xenotransplantation SCID model (direct human skin graft onto immunodeficient mice and intradermal injection of activated T cells) constitutes the model that more closely resembles the clinical situation. ${ }^{4,5}$ However, this model presents clear disadvantages, as it cannot be used as high throughput due to practical and ethical reasons.

We have established a skin-humanized mouse model consisting in bioengineered human skin grafted onto immunodeficient mice. ${ }^{6,7}$ This model allows the generation of large numbers of mice engrafted with a significant area of human skin by tissue engineering and circumvents problems related to heterogeneity and amount of human skin biopsy samples. Using this system several normal and pathological conditions have been successfully modeled in our laboratory (cutaneous wound healing, UV responses, and genodermatosis such as Epidermolysis Bullosa). ${ }^{8-10}$ Another advantage associated to this model is that individual cellular components may also be genetically manipulated during the amplification procedure, and this could contribute to dissect the cellular and molecular pathways contributing to the pathogenesis of the disease.

Modeling an inflammatory skin disorder such as psoriasis requires paying special attention to the immune component. A close relationship exists between $\mathrm{T} 1 / \mathrm{T} 2$ imbalance and the outcome of certain autoimmune diseases. It is well documented that activated T cells are in part responsible for the phenotypic changes observed in psoriatic skin. Among them, type $1 \mathrm{~T}$ cells appear to play a fundamental role in the pathogenesis of psoriasis. ${ }^{11}$ Another $T$ cell subset, called Th17, has been recently characterized as distinct from Th1 and Th2 cell subpopulations. These cells were initially reported to play important roles in the immunopathology of different experimental autoimmune mouse models including experimental autoimmune encephalomyelitis (EAE) ${ }^{12,13}$ and collageninduced arthritis (CIA) ${ }^{14,15}$ More recently Th17 cells have been identified in several human pathological conditions such as contact dermatitis, rheumatoid arthritis, Crohn's disease, and psoriasis. ${ }^{16-19}$ Thus, several authors have described the characteristic Th1/Th17 cytokine profile produced by $\mathrm{T}$ cells present in a psoriatic plaque, that provide large amounts of IL-2, IFN- $\gamma$, IL-22 and IL-17 and little or no IL-4 and IL-10. ${ }^{11,16-20}$

In addition to the immunological components, several studies in experimental mouse models have provided compelling evidence that both altered signaling pathways and a compromised barrier function in the epidermis play a fundamental role in the pathogenesis of the disease. ${ }^{3,21-24}$

Here we report the development and characterization of a new skin-humanized mouse model of psoriasis based on an experimental design that takes into account both the epidermal and the immune components. We describe an allogeneic version, containing cells from skin biopsies and blood samples of nonrelated healthy human donors and an autologous version in which skin and blood cells come from the same psoriatic patient. The psoriatic phenotype was developed after intradermal administration of in vitro derived T1 lymphocytes along with Th17 recombinant cytokines. In both cases, mild barrier disruption by tape stripping was necessary to fully develop the psoriatic phenotype. Thus, we have demonstrated in the skin-humanized model system that a healthy normal human skin might develop a psoriasis phenotype in the presence of the adequate signals provided by a wounding stimulus and of the appropriate cytokines produced by specific lymphocyte subpopulations (Th1/Th17). In both systems (autologous and allogeneic), the key factor contributing to the generation of the psoriatic plaque lay in the presence of reciprocal signaling activation cascades elicited by both keratinocytes in the epidermis and lymphocytes that were administered to the dermal compartment.

\section{Materials and Methods}

\section{Patients}

All patients included in this study showed the psoriasis vulgaris variant of the disease, with early-onset and high PASI scores. Some of them also showed family history of the disease. At the time skin biopsies were taken, medication had been discontinued for several months. Samples were obtained under local anesthesia from either symptomless skin or plaque by using a 6-mm biopsy punch. Psoriatic patients were recruited from Hospital Básico de la Defensa (Valencia, Spain) and signed an informed consent.

\section{Lymphocyte Isolation and T Cell Expansion}

Peripheral blood from psoriatic patients or buffy coats from HIV-seronegative donors (provided by Centro de Transfusiones, Madrid, Spain) were used to isolate PBMCs by Ficoll-Hypaque (Pharmacia, Piscataway, NJ) gradient centrifugation. Cells were resuspended in RPMI 1640 , supplemented with $10 \%$ heat-inactivated fetal calf serum, and stimulated with Dynabeads ${ }^{\circledR}$ CD3/CD28 T Cell Expander (ratio 1:1) and $30 \mathrm{U} / \mathrm{ml}$ human interleukin-2 (R\&D Systems Inc., Minneapolis, MN) for 4-6 days. For T1 differentiation, IL-12 (20 ng/ml) (R\&D Systems Inc.) plus anti-IL-4 (5 $\mu \mathrm{g} / \mathrm{ml})$ (BD Pharmingen, San Diego, CA) were also added to the culture. Th1 cells were obtained after negative selection using the $\mathrm{CD} 4^{+} \mathrm{T}$ cell isolation kit from Miltenyi Biotec (Auburn, CA).

\section{Flow Cytometry Analysis}

Phenotype analysis of lymphocyte subpopulations, before and after T cell expansion, was carried out by flow cytometry (FCM) using an EPICS cytofluorometer (Beckman Coulter, Fullerton, CA). Cells were harvested, washed, and suspended in phosphate-buffered saline with $1 \%$ bovine serum albumin (Sigma-Aldrich, St Louis, $\mathrm{MO})$. Aliquots $\left(2 \times 10^{5}\right.$ cells) were incubated in the dark 
at $4^{\circ} \mathrm{C}$ (30 minutes) with conjugated monoclonal antibodies and washed. Monoclonal antibodies against human CD3, CD4, CD8, CD25, CD69, HLA-DR, CD44, and CD62L were obtained from Becton Dickinson (San Jose, CA). Nonspecific fluorescence was determined using the appropriate isotype controls. For intracellular staining of cytokines, cells were stimulated for 5 hours with phorbol myristate acetate (PMA) and ionomycin in the presence of monensin (GolgiStop from Pharmingen). Cells were then labeled for surface CD8, fixed in $4 \%$ paraformaldehyde for 10 minutes, and permeabilized with $0.1 \%$ saponin. The staining was performed with anti-IFN $\gamma$, anti-IL-2, anti-IL-4, and anti-IL-10 antibodies (PE or FITC conjugated, Pharmingen) in the presence of $0.1 \%$ saponin. Finally, cells were washed and subjected to FACS analysis. In vitro cultured healthy donor and psoriatic patient keratinocytes and fibroblasts were stained after trypsinization with FITC anti-HLA-DR and with PE anti-HLA-A,B,C (Becton Dickinson, San Jose, CA). FACS analysis was also performed after exposure to cell supernatants derived from allogeneic in vitro derived T1 lymphocytes. Nonspecific fluorescence was determined using the appropriate isotype controls.

\section{Primary Cultures of Human Keratinocytes and Fibroblasts}

Human keratinocytes and dermal fibroblasts were isolated from donor/patient skin biopsies by enzymatic digestion. The study was conducted according to the Declaration of Helsinki Principles. Primary keratinocytes were cultured on a feeder layer of lethally irradiated (X-ray; 50 Gy) 3T3-J2 cells (a gift from Dr J. Garlick, SUNY, Stony Brook, NY) as previously described. The keratinocyte seeding media was a 3:1 mixture of Dulbecco's Modified Eagle Medium (DMEM) (GIBCO-BRL, Gaithersburg, MD) and HAM'S F12 (GIBCO-BRL) containing 10\% fetal calf serum, $0.1 \mathrm{nmol} / \mathrm{L}$ choleric toxin, $2 \mathrm{nmol} / \mathrm{L} \mathrm{T3}, 5 \mu \mathrm{g}$ per $\mathrm{ml}$ insulin, and $0.4 \mu \mathrm{g}$ per $\mathrm{ml}$ hydrocortisone and $10 \mathrm{ng}$ per $\mathrm{ml}$ EGF (Sigma-Aldrich). Primary fibroblasts were cultured on plastic in DMEM containing $10 \%$ fetal calf serum. Cells were cultured at $37^{\circ} \mathrm{C}$ in a humid atmosphere containing $5 \% \mathrm{CO}_{2}$. The culture medium was changed every 2 days.

\section{Animals}

Immunodeficient Rj: NMRI-Foxn1 ${ }^{\text {nu }}$ (NMRI nu) mice (6-8 weeks old) were used (Elevage Janvier, Le Genest Saint Isle, France). Mice were housed for the duration of the experiment at the CIEMAT Laboratory Animals Facility (Spanish registration number 28079-21A) in pathogenfree conditions using microisolators, individually ventilated cages type IIL, at a maximum of six mice per cage, with 25 air cage changes per hour and heat-treated soft wood pellets as bedding. All experimental procedures were carried out according to the European and Spanish laws and were in keeping with regulations on the protection and use of animals in scientific research. Procedures were approved by the Animal Experimentation Ethical
Committee of the CIEMAT according to all external and internal biosafety and bioethics guidelines.

\section{Bioengineered Human Skin Equivalents and Grafting}

The bioengineered human skin equivalent is based on the use of fibrin containing live fibroblasts as a dermal component. Briefly, $1.5 \mathrm{ml}$ of fibrinogen solution (from cryoprecipitated pig blood) were added to $5 \mathrm{ml}$ of keratinocyte growth medium containing $2.5 \times 10^{5}$ dermal fibroblasts and $250 \mathrm{IU}$ of bovine aprotinin (Trasylol; Bayer, West Haven, Connecticut). Immediately after, 0.5 $\mathrm{ml} \mathrm{Cl} \mathrm{Ca}_{2} 0.025 \mathrm{mmol} / \mathrm{L}$ with $5.5 \mathrm{IU}$ of bovine thrombin (Sigma-Aldrich) was added. The mixture was placed on a 6-well culture plate (Corning Costar Corp., Cambridge, MA) and allowed to solidify at $37^{\circ} \mathrm{C}$ for 2 hours. Keratinocytes were then seeded and grown submerged up to confluence. Mice were aseptically cleansed and grafted as previously described elsewhere.

\section{Intradermal Injection of T Lymphocyte Subpopulations and Recombinant Cytokines}

Nine to 12 weeks after transplantation, when the maturation of the regenerated human skin is complete, recombinant cytokines (200 ng/50 $\mu \mathrm{l})$, and/or in vitro derived T lymphocyte subpopulations $\left(10^{6} / 50 \mu \mathrm{l}\right)$ diluted in sterile PBS were inoculated by intradermal injection into the stable engrafted human skin every other day for two weeks. Where indicated, the same skin area was tape stripped 15 times before injection. Mice were sacrificed by carbon dioxide asphyxiation two days after the last intradermal injection and skin biopsies were taken and processed for histological and immunohistochemical analysis.

\section{Histology, Immunohistochemistry, and Immunofluorescence}

Formalin-fixed paraffin sections $(4-6 \mu \mathrm{m})$ were dewaxed by melting for $30-60$ minutes at $60^{\circ} \mathrm{C}$, cleared in xylene three times for 5 minutes, and rehydrated in water solutions containing decreasing percentages of ethanol. To determine tissue architecture, sections were stained with hematoxylin-eosin (Gill 2 Hematoxylin and Eosin Y alcoholic; Thermo Sandon, Cheshire, UK) following a standard procedure.

For the immunoperoxidase staining, sections were then treated for endogenous peroxidase inactivation, blocked, and incubated overnight at $4^{\circ} \mathrm{C}$ with specific primary antibodies against human epidermal and granulocyte markers. The antibodies were used at final dilutions of 1:500 and 1:300 for anti-keratin 1 and antikeratin 17 rabbit polyclonal antibodies (Sigma-Aldrich), respectively, 1:1000 for anti-keratin 6 monoclonal antibody (clone LHK6B, Neomarkers, Fremont, CA), 1:2000 for loricrin rabbit polyclonal antibody (Babco, Richmond, $\mathrm{CA}$ ), 1:50 for anti-myeloperoxidase (MPO) (HyCult bio- 
technology b.v., Uden, The Netherlands), and 1:500 for anti-psoriasin/HID5/S100A7 rabbit polyclonal antibody (Imgenex, San Diego, CA). T-cell subpopulations have been characterized using anti-CD4 (clone 4B12, Dako, Glostrup, Denmark) and anti-CD8 (clone SP16, Master Diagnóstica, Granada, Spain) specific antibodies. To establish the human origin of the regenerated skin, a human-specific antibody against involucrin (clone SY5; Sigma-Aldrich) was used to label human keratinocytes. Cell proliferation was assessed using the anti-Ki-67 rabbit monoclonal antibody purchased from Neomarkers (clone SP6). Specific biotinylated secondary antibodies were obtained from Jackson ImmunoResearch Laboratories (West Grove, PA). All immunoperoxidase stainings were performed with standard procedures using the Vectastain ABC kit (Vector Laboratories Inc., Burlingame, CA). For alkaline phosphatase staining, anti-human CD3 $\varepsilon$ rabbit polyclonal antibody (Dako, Glostrup, Denmark), alkaline phosphatase-conjugated donkey anti-rabbit secondary antibody (Jackson ImmunoResearch Laboratories), and alkaline phosphatase substrate kit I (Vector) were used. Sections were counterstained with hematoxylin and dehydrated in water solution containing increasing percentages of ethanol. Finally, the slides were placed 15 minutes in histoclear (National diagnostic, Atlanta, GA) and mounted. Images were taken using an Olympus Bx41 microscope and digital camera.

Immunofluorescence was performed on 8- to 10- $\mu \mathrm{m}$ cryostat sections of tissue samples adjacent to those used for the above mentioned immunohistochemical evaluation, embedded in optimal cutting temperature (OCT) (Tissue-Tek) medium. Vascular density was determined in snap-frozen tissue sections fixed with cold acetone. Slides were incubated with monoclonal antibody against mouse CD31 (PECAM-1) (clone MEC13.3, PharMingen) diluted 1:100. Double immunofluorescence was performed with anti-ICAM-1 goat polyclonal antibody diluted 1:50 (Santa Cruz Biotechnology, Santa Clara, CA).

\section{Results}

\section{Experimental Design for the Generation of a Skin-Humanized Model with Psoriatic Phenotype}

The contribution of both epidermal and immune components to the pathogenesis of the disease was considered as a critical factor for the experimental design presented here, to mimic the human condition as much as possible. We took advantage of the skin-humanized mouse model previously characterized in our laboratory, based on the permanent engraftment of a bioengineered human skin onto the back of immunodeficient mice. ${ }^{6,7}$ This system yields large numbers of mice engrafted with a significant area of single donor-derived human skin, an advantage compared to other xenotransplantation models. ${ }^{4,5}$ The present model was generated using keratinocytes and fibroblasts isolated by enzymatic digestion of skin biopsies from either healthy donors (Figure 1A) or psoriatic patients (Figure 1B). Cells were amplified in culture, as- sembled in a fibrin-based organotypic culture, and grafted to immunodeficient mice.

The T1 lymphocyte subset was obtained by in vitro cytokine-directed polarization of peripheral blood isolated $T$ cells. These immune cells were reintroduced in the regenerated mature human skin by intradermal injection. The Th17 cytokines IL-17 and IL-22 were coadministered as recombinant proteins. The epidermal barrier was disrupted by using tape-stripping, a well-characterized method that removes the superficial layers of the stratum corneum and leads to hyperproliferation without severe inflammation. ${ }^{25}$

\section{In Vitro Differentiation of T1 Cell Subpopulations}

We differentiated T cells toward a type 1 phenotype by in vitro activation and cytokine-directed polarization. To this end, PBLs obtained by density gradient separation either from psoriatic patients or healthy donors were activated using a combination of CD3/CD28 antibodies conjugated to magnetic beads in the presence of IL-2. T1 and T2 differentiation is controlled by IL-12 (p35-p40) and IL-4, respectively. Moreover, these cytokines are known to inhibit the generation of the opposite T subset. Thus, we used a well-established method to obtain cytokine-directed $\mathrm{T} 1$ polarization, by culturing the activated $\mathrm{T}$ lymphocytes for 6 days in the presence of IL-12 and antiIL-4. TO cells correspond to activated T lymphocytes cultured in the presence of IL-2 alone. At that time, the proportion of $\mathrm{CD}^{+}$cells varied from $70 \%$ to $90 \%$ depending on the donor, with a CD4:CD8 ratio of 1.2-1.8. The activation status was evaluated by cell surface expression of CD25 (IL-2R $\alpha$ ), HLA-DR and CD69. FACs profiles from a normal healthy donor are shown in Figure 2A. After 6 days of culture, a high percentage of $\mathrm{CD} 4^{+}$ cells also expressed CD25 (66.61\% of $\mathrm{CD}^{+}{ }^{+} \mathrm{T} 1$ cells vs. $73.61 \%$ of $\mathrm{CD} 4^{+} \mathrm{TO}$ cells). The proportion of $\mathrm{CD} 8^{+}$cells coexpressing CD25 was lower $\left(44.71 \%\right.$ of $\mathrm{CD} 8^{+} \mathrm{T} 1$ cells vs. $54.49 \%$ of $\mathrm{CD}^{+}$T0 cells). Both in the $\mathrm{CD}^{+}$and $\mathrm{CD}^{+} \mathrm{T}$ cell population, a high proportion of cells expressed HLA-DR under T0 or T1 polarizing conditions (78.64\% of $\mathrm{CD}^{+}{ }^{+} \mathrm{T} 1$ cells vs. $91.61 \%$ of $\mathrm{CD}^{+}{ }^{+} \mathrm{TO}$ cells and $71.82 \%$ of $\mathrm{CD}^{+}{ }^{+} \mathrm{T} 1$ cells vs. $74.06 \%$ of $\mathrm{CD}^{+}{ }^{+} \mathrm{TO}$ cells). In contrast, the early activation marker showed low expression levels, especially under T1 polarizing condition $\left(6.61 \%\right.$ of $\mathrm{CD}^{+}$and $2.60 \%$ of $\mathrm{CD}^{+}$in $\mathrm{T} 1$ cells vs. $14.52 \%$ of $\mathrm{CD}^{+}$and $17.62 \%$ of $\mathrm{CD}^{+}{ }^{+}$in T0 cells). Surface expression levels of CD44 and CD62L were also analyzed on activated T0 and T1 cells (see Supplemental Figure $1 \mathrm{~A}$ at $h$ ttp://ajp.amjpathol.org). Almost all $\mathrm{CD} 4^{+}$ $(89.7 \%)$ and more than half of the $\mathrm{CD}^{+}(59.1 \%) \mathrm{T} 1$ cells expressed CD44. The expression levels of CD62L revealed that $60.4 \%$ of $\mathrm{CD}^{+}$cells are effector $\mathrm{T}$ cells, whereas $64.7 \%$ of $\mathrm{CD}^{+} \mathrm{T}$ cells are CD62L-negative.

The cytokine profile of the in vitro differentiated T cells analyzed in Figure 2A was also evaluated by flow cytometry on $\mathrm{CD}^{+}$and $\mathrm{CD} 8^{+} \mathrm{T}$ cell subsets after their stimulation with phorbol myristate acetate (PMA) and ionomycin. By day 6 of T1 differentiation a large percentage of cells expressed IFN- $\gamma$ (42.9\% compared to $21.69 \%$ ex- 
A

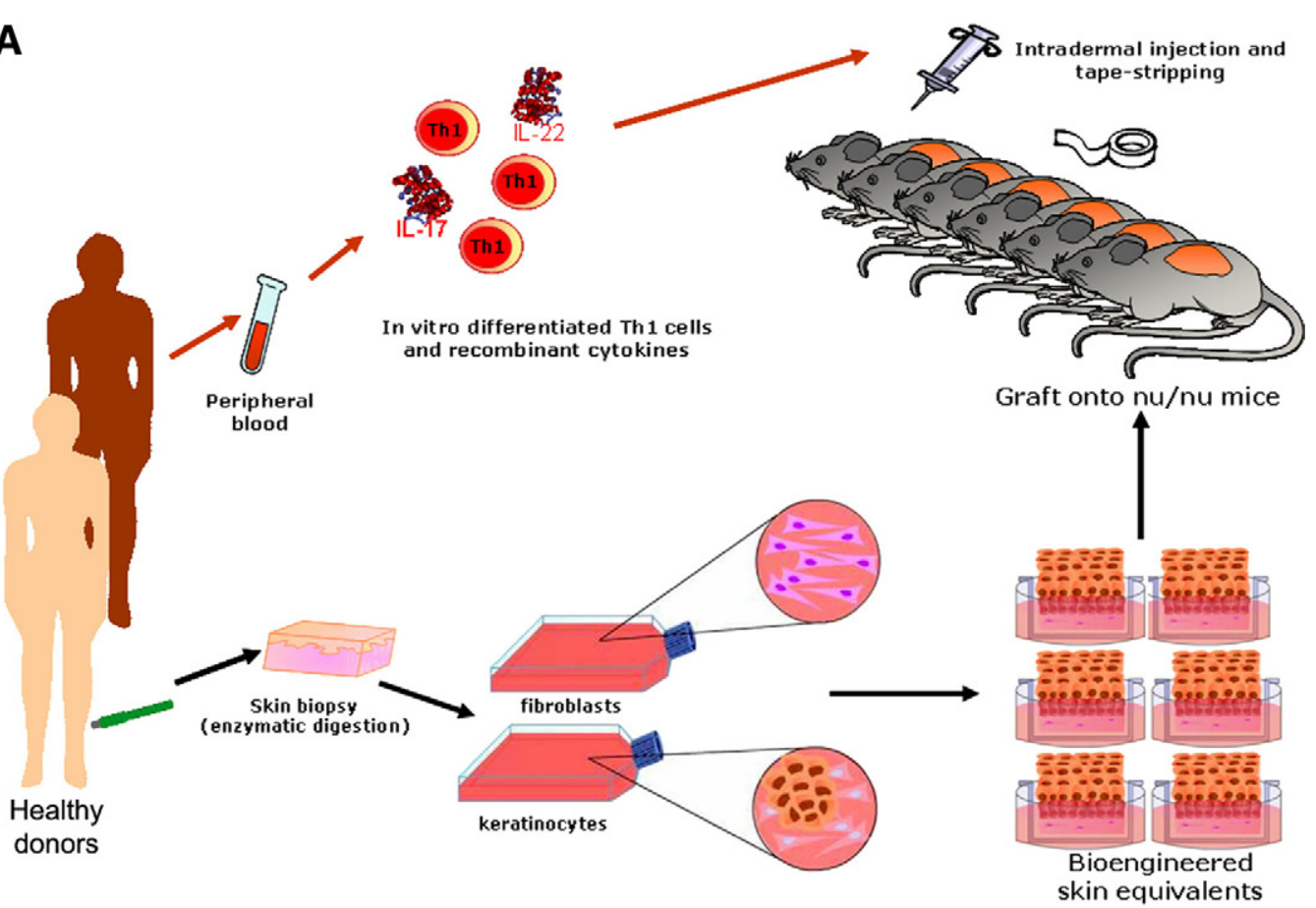

B

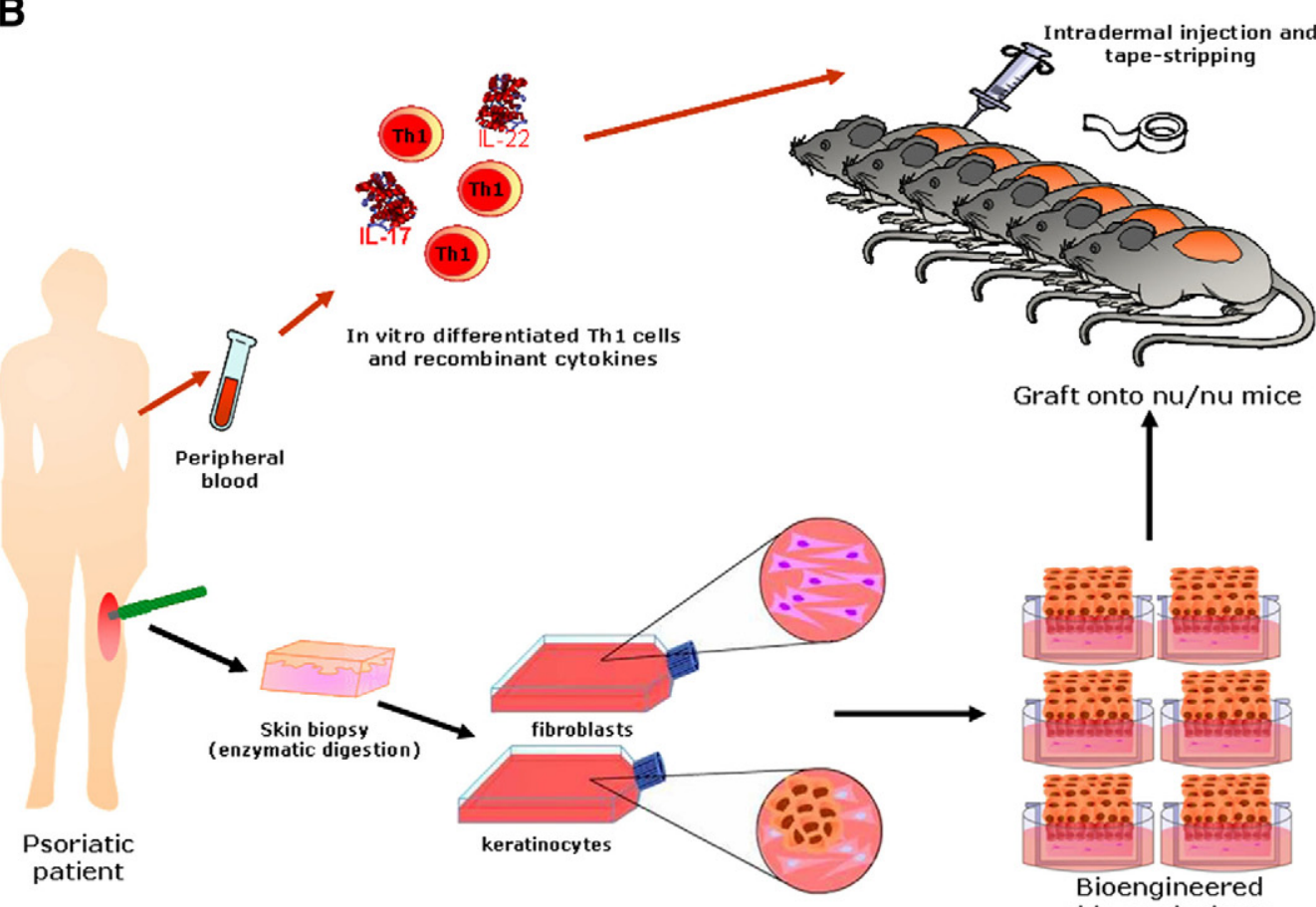

Figure 1. Schematic diagram of the experimental design for the generation of a skin-humanized mouse model with psoriatic phenotype. A: Allogeneic healthy donors. B: Autologous psoriatic patients.

pressing T0 cells at day 6) when activated. A reduced proportion of cells expressed IL-2 (22.39\% compared to $42.69 \%$ expressing T0 cells) and only a small proportion of T1 and T0 cells expressed IL-4 and IL-10 (Figure 2B). T1 cells also produced large amounts of GM-CSF as assessed by a specific ELISA assay (data not shown). Similar percentages were obtained in the activation and cytokine profile analyses after in vitro cytokine-directed
T1 polarization of psoriatic lymphocytes, although certain heterogeneity existed among patients (data not shown).

We also analyzed the surface levels of expression of HLA class I and class II on donor keratinocytes and fibroblasts (see Supplemental Figure 1B at http://ajp. amjpathol.org). In vitro cultured healthy donor and psoriatic patient keratinocytes used to assemble skin equivalents to regenerate human skin on nude mice were 

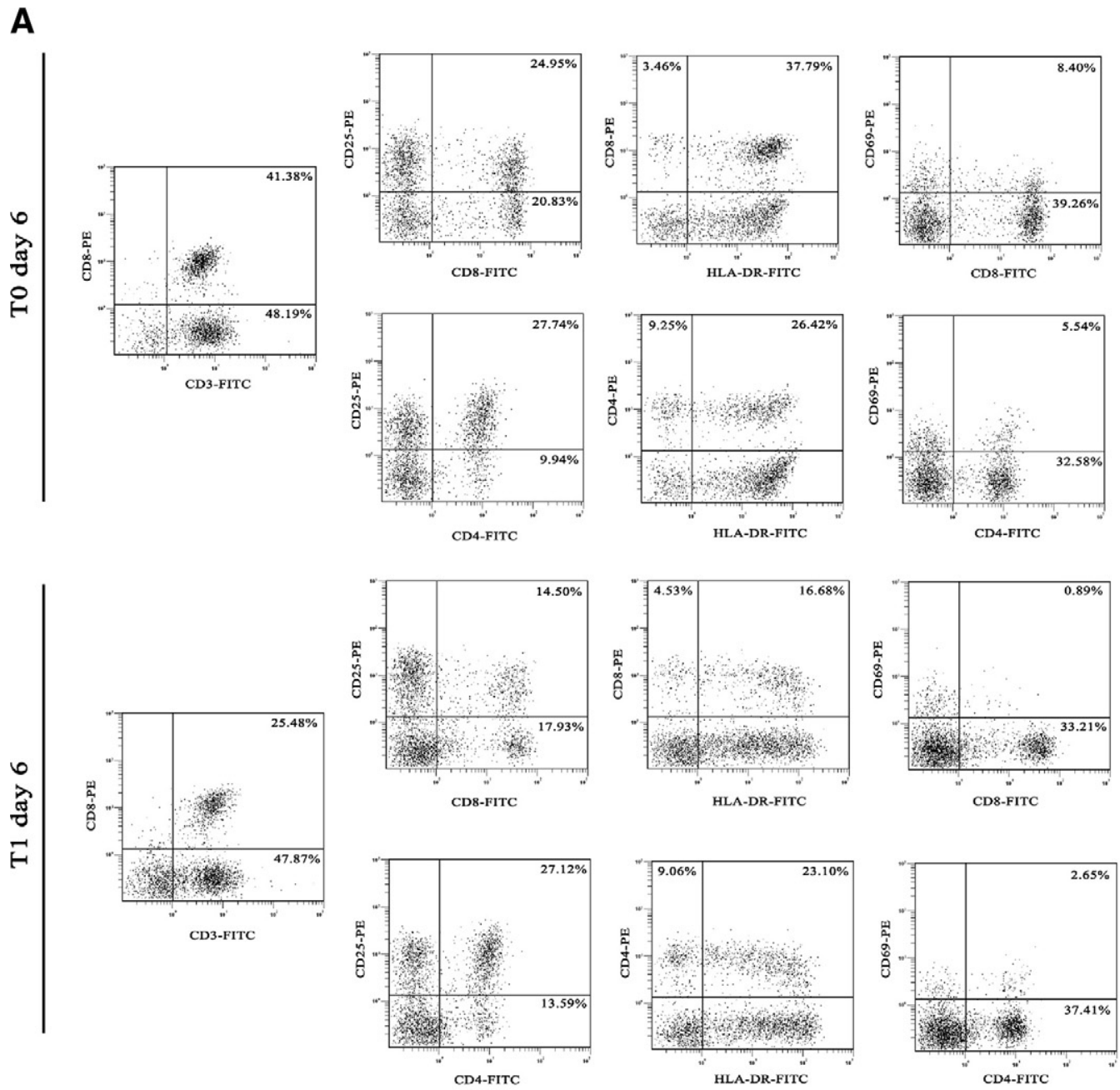

\section{B}
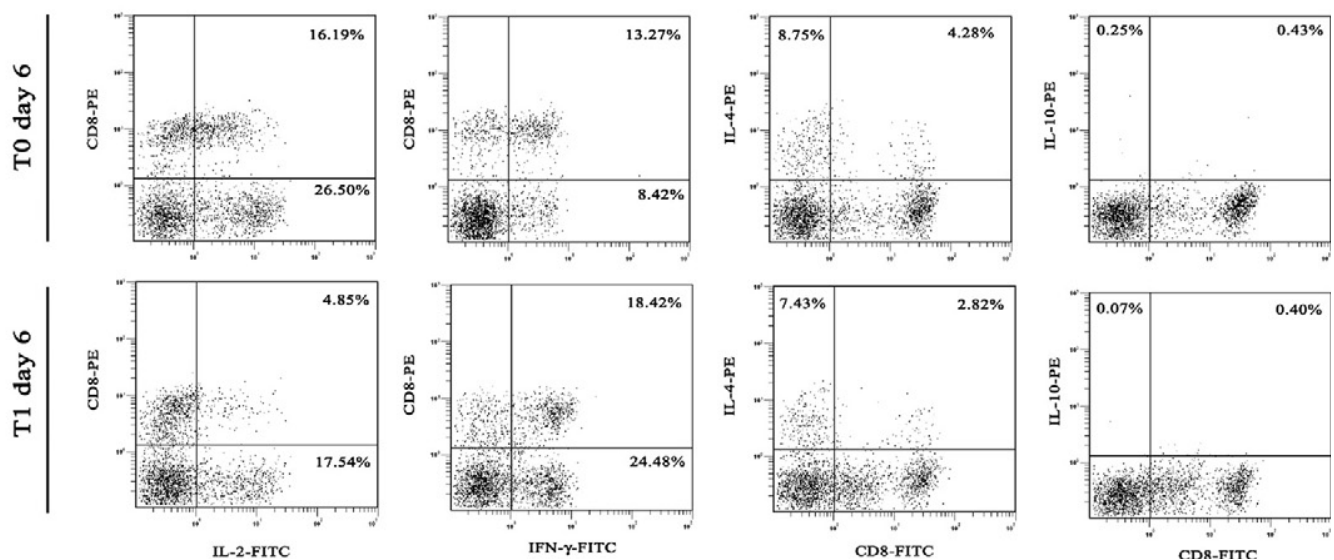

Figure 2. Flow cytometric analysis of in vitro differentiated T cell subpopulations. PBLs from a healthy donor were cultured with Dynabeads CD3/CD28 T Cel Expander (ratio 1:1) and $50 \mathrm{U} / \mathrm{ml}$ human interleukin-2. Cells were cultured for 6 days under these conditions (T0), and IL-12 plus anti-IL-4 were also added to the culture for T1 differentiation. Flow cytometric analysis was performed at day 6 of differentiation. A: Representative dot plots of cell-surface markers on in vitro-differentiated T0 and T1 cell populations. B: Dot plot pattern of intracellular cytokine staining. Percentages refer to the proportion of positive cells as defined by the binding of the control antibodies. One of three independent experiments is shown.

stained with FITC anti-HLA-DR and with PE anti-HLA$A, B, C$. After exposure of these keratinocytes to 24 hour supernatants from allogeneic in vitro derived T1 lymphocytes, HLA class II expression was induced. However, a large heterogeneity was found between samples (per- centages of induction from 5\% to 53\%). Similarly, an increase in HLA class I expression was found in keratinocytes under the same experimental conditions [foldincrease of Mean fluorescence intensity (MFI) from $1.8 \times$ to $2.2 \times$ ]. HLA-DR and HLA class I expression 
PBS1x
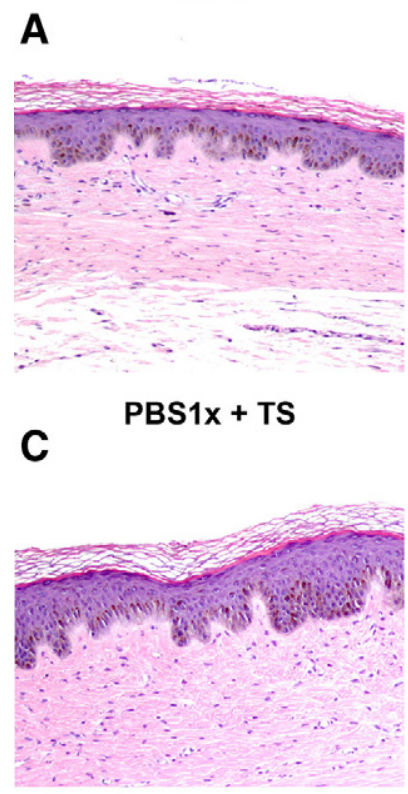

$\mathrm{T} 1+\mathrm{IL}-22$

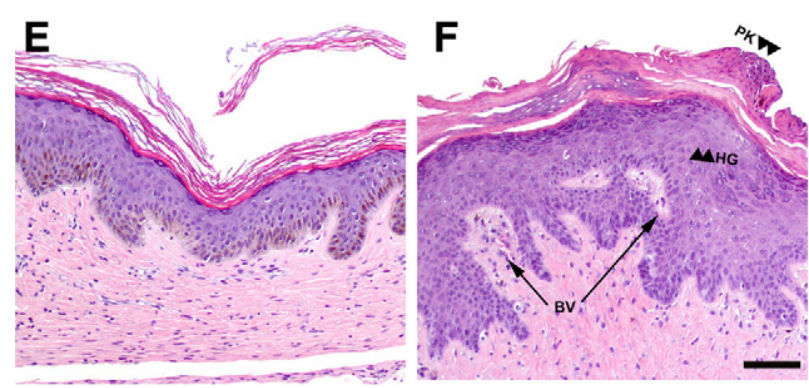

Figure 3. Histological analysis in the allogeneic skin-humanized mouse model. H\&E staining was performed on formalin-fixed paraffin-embedded sections of human skin grafts treated with PBS (A) or those injected intradermally with in vitro-differentiated lymphocyte subpopulations and/or recombinant IL-22 and IL-17 cytokines. Tape-stripping (TS) was applied where indicated $(\mathbf{B}, \mathbf{C}, \mathbf{D}$, and $\mathbf{F})$. Arrowheads show focal areas of hypogranulosis (HG) and paraketosis (PK) were observed when human grafted skin was injected with recombinant cytokines plus T1 lymphocytes and tape-stripping (TS) was applied (B, D, and $\mathbf{F})$. Arrows show the presence of dilated blood vessels (BV). Scale bar $=100 \mu \mathrm{m}$. Images are representative of two independent experiments with two to three mice per group.

was also induced at different levels in fibroblasts upon incubation with T1 derived supernatants. Thus it can be concluded that in vitro cultured fibroblasts and keratinocytes from healthy donors or psoriatic patients do not express substantial levels of HLA-DR after their expansion. Exposure to cell supernatants derived from allogeneic in vitro derived T1 lymphocytes induced the expression of HLA class I and II (see Supplemental Figure 1B at http://ajp.amjpathol.org).

\section{Intradermal Injection of T1 Differentiated Lymphocytes and Recombinant Cytokines in the Allogeneic Skin-Humanized Mouse Model}

Histological analyses showed that injection of T1 lymphocytes together with recombinant IL-22 and tape stripping (Figure 3B) induced the typical epidermal changes as- sociated with psoriasis, including elongation and fusion of rete ridges, focal acanthosis, parakeratosis, and partial loss of the granular layer over treatment with PBS alone (Figure 3A). The dermis was characterized by an influx of inflammatory cells and increased vascularity with the presence of dilated capillaries. A similar reaction was also observed when recombinant IL-17 was also added to the above-mentioned combination, but even a stronger dermal inflammatory response was observed in the presence of this cytokine (Figure 3F). To exclude the possibility of an adverse reaction due to allogeneic recognition, $\mathrm{CD}^{+}$cells were depleted using anti-CD8 magnetic beads before each injection. In this case, the major characteristics associated to a psoriatic phenotype were also present (Figure 3, D and F). In contrast, T1 plus recombinant IL-22 injection did not induce the psoriatic phenotype in the absence of tape-stripping; only a slight increase in epidermal thickness was observed (Figure 3E). Injection of recombinant IL-17 concomitant with tapestripping did not induce hyperproliferation in epidermis but induced an increase in dermal cellularity with high numbers of $\mathrm{MPO}^{+}$cells (see Supplemental Figure 2, A-J at http://ajp.amjpathol.org). Similarly, the result of tapestripping alone was far from resembling a psoriasiform reaction (Figure $3 \mathrm{C}$ ). Histological analyses showed that in contrast to T1 lymphocytes, injection of T0 lymphocytes together with recombinant Th17 cytokines and tape stripping did not induce epidermal changes associated with psoriasis (Figure 4A). No epidermal changes were induced by injection of T1 subpopulation and tape-stripping (Figure 4B). Similarly, in the absence of injected lymphocytes neither IL-22 nor IL-17 in combination with tape stripping were able to cause noticeable epidermal alterations (Figure 4, C-E). Proliferative activity in the epidermis of the regenerated human skin injected with IL-22 plus tape-stripping appears to be slightly increased (see Supplemental Figure 2, F and $\mathrm{H}$ at http://ajp.amjpathol.org). T1 cells plus IL-22 (data not shown) or tape-stripping alone did not induce a significant increase in proliferation (Figure 5). However, when T1 cells were coadministered with IL-22 and IL-17 concurrently with tape-stripping a visible increase in Ki-67 immunostaining was observed. In this case, positive cells were not only restricted to the basal layer but included also suprabasal keratinocytes (Figure 5).

\section{Epidermal and Dermal Changes Observed in the Allogeneic Skin-Humanized Mouse Model}

Some of the anomalies found in psoriatic lesions were identified by immunohistochemical analyses of several markers of keratinocyte differentiation (involucrin, loricrin and keratin 1 expression) and proliferation (keratin 6, keratin 17 and S100A7). The coinjection of T1 cells plus recombinant $\mathrm{IL}-22$ and/or $\mathrm{IL}-17$ in skin grafts together with tape-stripping showed some of the most representative immunohistochemical features of human psoriatic epidermis. Involucrin appeared to be up-regulated, whereas loricrin expression was reduced in areas where the generation of a well differentiated granular layer was impaired. Keratin expression was also disrupted with 
$\mathrm{T} 0+\mathrm{IL}-17+\mathrm{IL}-22+\mathrm{TS}$

T1 + TS

A

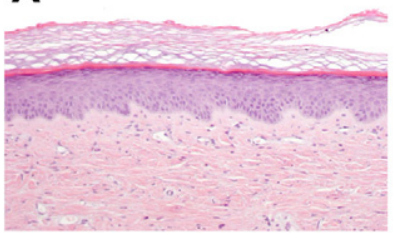

$\mathrm{IL}-17+\mathrm{TS}$
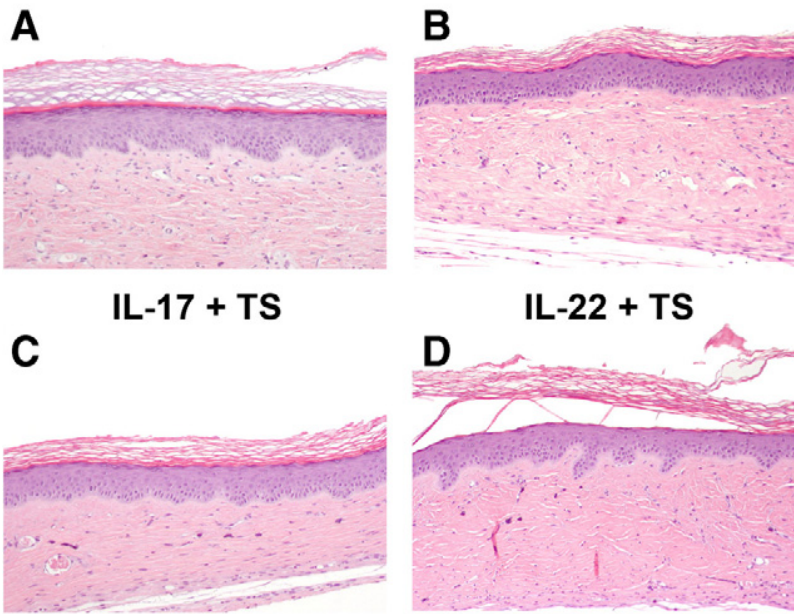

IL-22 + TS

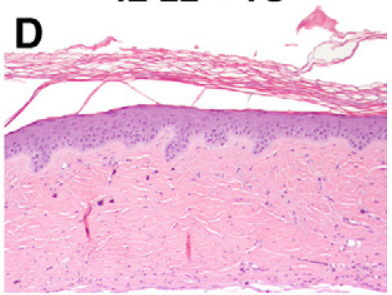

\section{E T1 + IL-17+TS}

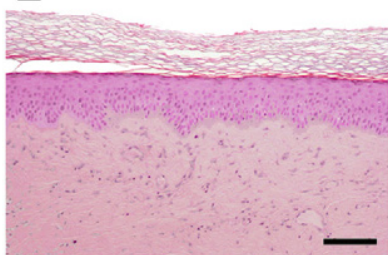

Figure 4. Histological analysis of controls in the allogeneic skin-humanized mouse model. H\&E staining was performed on formalin-fixed paraffinembedded sections of human skin grafts that were injected intradermally with (A) in vitro nondifferentiated lymphocyte subpopulations (T0) together with recombinant IL-22 and IL-17 cytokines. B: In vitro differentiated lymphocyte subpopulations (T1). C: Recombinant IL-17. D: Recombinant IL-22. E: In vitro differentiated lymphocyte subpopulations (T1) together with recombinant IL-17. Tape-stripping (TS) was applied where indicated. Scale bar $=100 \mu \mathrm{m}$.

focal down-regulation of K1 (Figure 6A). A clear upregulation of $\mathrm{K} 6$ and $\mathrm{K} 17$ expression was coincident with the presence of a hyperproliferative epidermis. In these cases, the antimicrobial protein S100A7 (psoriasin) was also induced (Figure 6B).

Despite the lack of obvious alterations at the histological level (H\&E staining) slight changes in the differentiation program were observed. In fact, we found deregulation of loricrin expression in conditions which include the presence of the recombinant IL-22 cytokine such as T1 coadministered with IL-22 together with tape stripping (Figure 6A), IL-22 concomitantly with tape stripping (see Supplemental Figure 2D at http://ajp.amjpathol.org) and
A involucrin

离的标
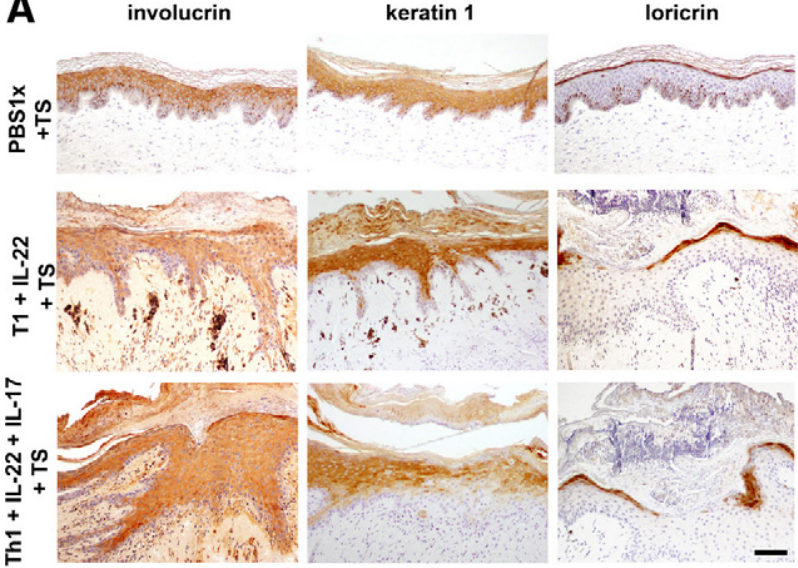

B
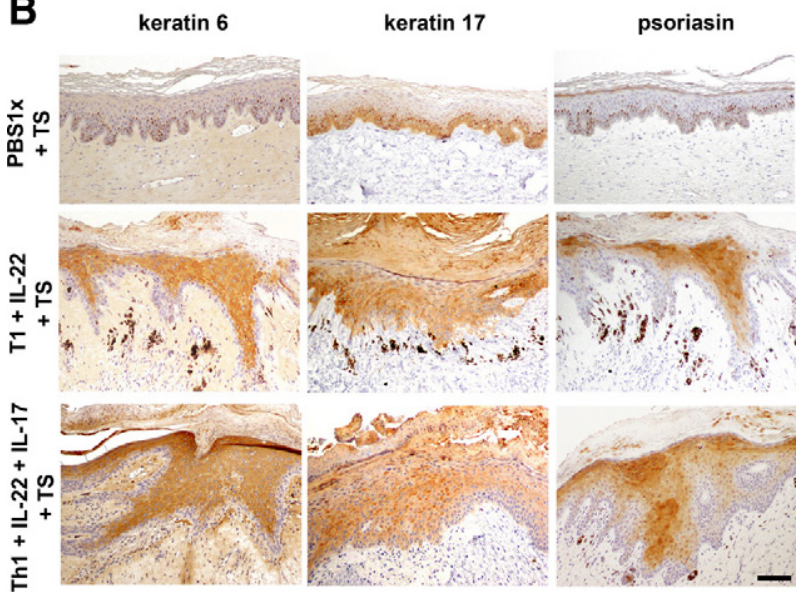

Figure 6. Immunohistochemical analysis of epidermal markers in the allogeneic skin-humanized mouse model. A: Consecutive formalin-fixed paraffin-embedded sections used in Figure 3 were stained for involucrin, keratin 1 , and loricrin differentiation markers. Scale bar $=100 \mu \mathrm{m}$. B: K6, K17, and psoriasin (hS100A7; markers of hyperproliferation in psoriasis) staining was also performed in serial sections. Scale bar $=100 \mu \mathrm{m}$.

T0 coadministered with IL-22 and IL-17 accompanied by tape stripping (data not shown).

A more prominent inflammatory infiltrate was observed in the upper dermis when recombinant IL-17 was coadministered with $\mathrm{T} 1$ cells and $\mathrm{IL}-22$ to regenerated human skin together with tape-stripping (Figure 3). Immunohistochemical analyses to assess the cellular composition of the infiltrate revealed an increased influx of granulocytes. In fact, we showed that concomitant injection of IL-17 and tape-stripping resulted in a noticeable recruitment of $\mathrm{MPO}^{+}$cells to the dermis of humanized skin (see Sup-

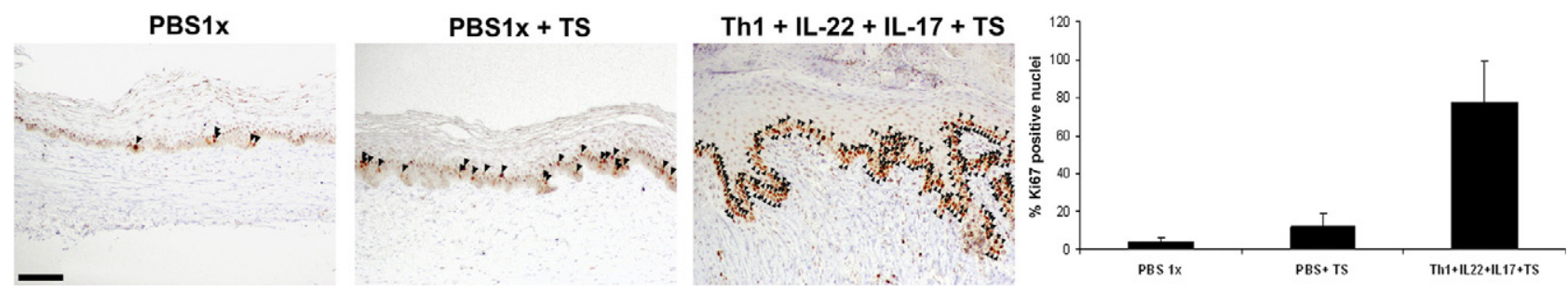

Figure 5. Epidermal proliferative response in the allogeneic skin-humanized mouse model. For immunohistochemical analysis of cell proliferation, immunostaining with anti-Ki-67 antibody was used. Arrowheads indicate the presence of positive nuclei. Scale bar $=100 \mu \mathrm{m}$. A proliferation index was calculated from the formula: (number of Ki-67-positive nuclei/total nuclei) $\times 100$. 

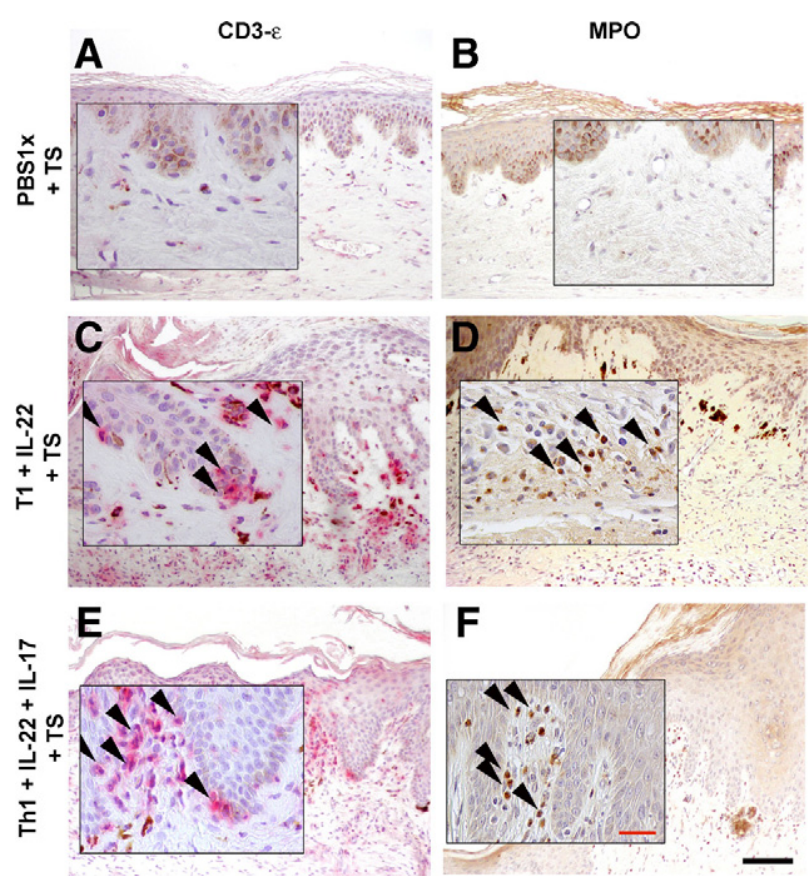

Figure 7. Immunohistochemical analysis of dermal inflammatory cells in the allogeneic skin-humanized mouse model. The composition of the inflammatory infiltrate was analyzed by immunohistochemical analysis of consecutive formalin-fixed paraffin-embedded tissue sections using specific antibodies against anti-myeloperoxidase (MPO) to detect cells of the granulocyte series $(\mathbf{B}, \mathbf{D}$ and $\mathbf{F})$ and anti-CD3- $\varepsilon \mathrm{T}$ cell specific antigen, to localize the injected human $\mathrm{T}$ cells in the tissue $(\mathbf{A}, \mathbf{C}$ and $\mathbf{E})$. The insets show a $\times 40$ magnification. The arrowheads indicate positive cell staining. Black Scale bar $=100$ $\mu \mathrm{m}$; red scale bar $=30 \mu \mathrm{m}$.

plemental Figure 2, I and $\mathrm{J}$ at http://ajp.amjpathol.org). The use of an anti-CD3- $\varepsilon$ specific antibody revealed the localization near the epidermis of the injected $T$ cells in the regenerated human skin (Figure $7, A-F$ ). The majority of $T$ cells present in the epidermis of grafts injected with T1 cells were of CD8 origin. However, elevated numbers of both $\mathrm{CD}^{+}$and $\mathrm{CD}^{+} \mathrm{T}$ cells were found predominantly in the dermis (see Supplemental Figure 3, A and B at http://ajp.amjpathol.org). In addition, some of the inflammatory cells of the infiltrate showed positive staining for specific dendritic cell markers (data not shown). CD31 staining showed the presence of dilated capillaries in the dermis of IL-22 and IL-17 plus T1 coinjected tapestripped regenerated human skin and correlated with an augmented ICAM-1 expression in dermal vessels (Figure 8).

\section{Autologous Skin-Humanized Mouse Model for Psoriasis}

The skin-humanized mouse model for psoriasis was also reproduced when keratinocytes and fibroblasts were obtained from a psoriatic plaque (Figure 1B). When skin equivalents generated using these cells were grafted onto the back of immunodeficient mice, the histological and immunohistochemical analyses showed that the regenerated human skin (Figure 9) was similar to that obtained using keratinocytes and fibroblasts from healthy donors, even when mild tape-stripping was applied (Figures 3 and 6 ). In vitro cytokine-directed polarization was used to obtain T1 lymphocyte subpopulations from the same psoriatic patients that were intradermally injected together with recombinant IL-22 and IL-17 cytokines. After barrier disruption by mild tape-stripping (Figure 9), the same changes in the epidermal compartment that were observed in the allogeneic model (Figures 3 and 6) were reproduced and constitute the typical histopathological features of psoriatic lesions: elongation and fusion of rete ridges, focal acanthosis, parakeratosis, and partial loss of the granular layer with focal down-regulation of keratin 1 and loricrin expression and up-regulation of keratin 17 and psoriasin (Figure 9). Findings included a strong angiogenic response and an inflammatory infiltrate that was very similar in composition to that obtained in the allogeneic model [ie, granulocytes (Figure 9) distributed in the upper dermis], together with the injected T1 lymphocytes that were found infiltrating the epidermis. We also demonstrated that the same changes associated with a psoriatic phenotype were observed when the injected T1 lymphocytes derived from unrelated healthy donors (data not shown).
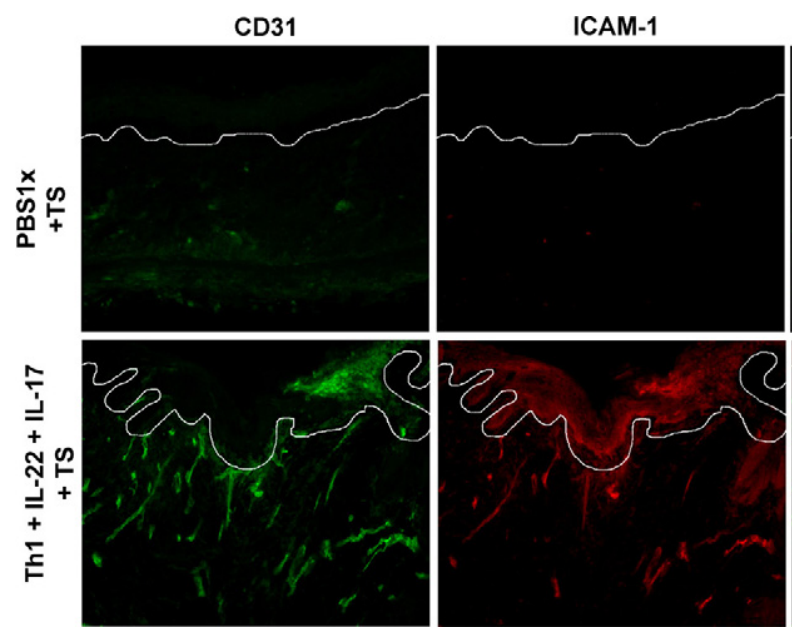

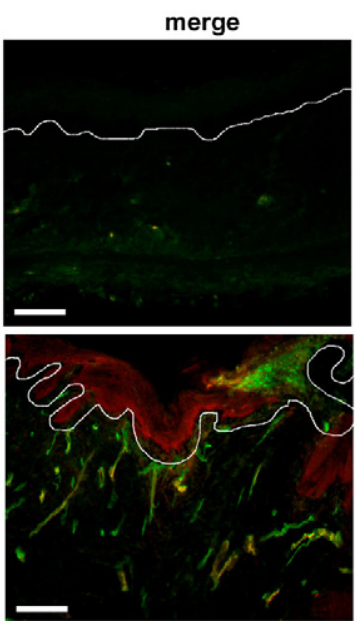

Figure 8. Immunofluorescence analysis of the angiogenic tissue reaction in the allogeneic skinhumanized mouse model. Double-labeling immunofluorescence analyses for endothelial cellspecific antigen CD31 and the intercellular adhesion molecule-1 (ICAM-1) is shown in cryostat sections that were obtained from tissue samples adjacent to those obtained for the immunohistochemical analyses. White lines indicate the basal membrane of the tissue. White scale bar $=100 \mu \mathrm{m}$. 
PBS1x + TS
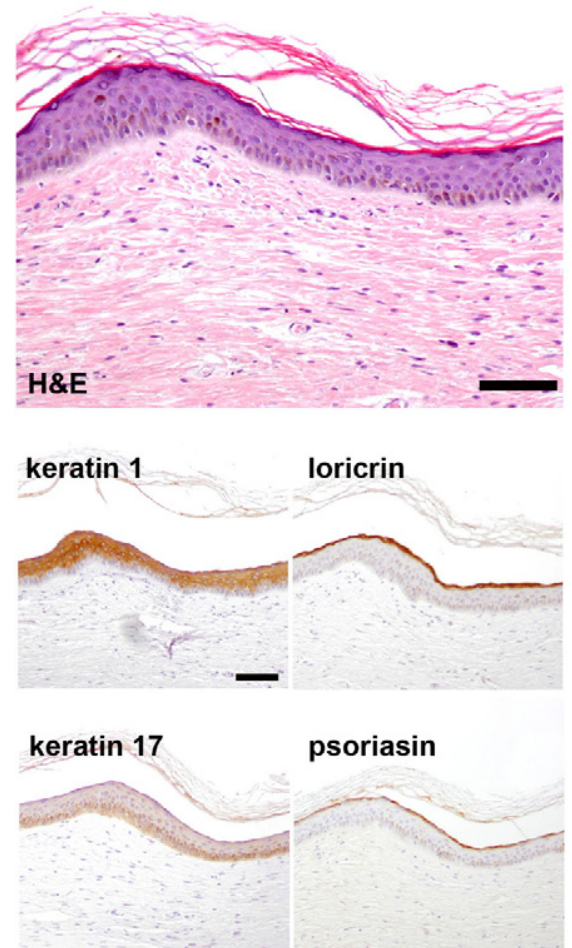

CD3-E MPO
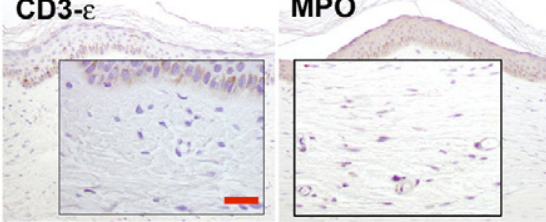

$\mathrm{T} 1+$ + IL-22 + IL-17 + TS

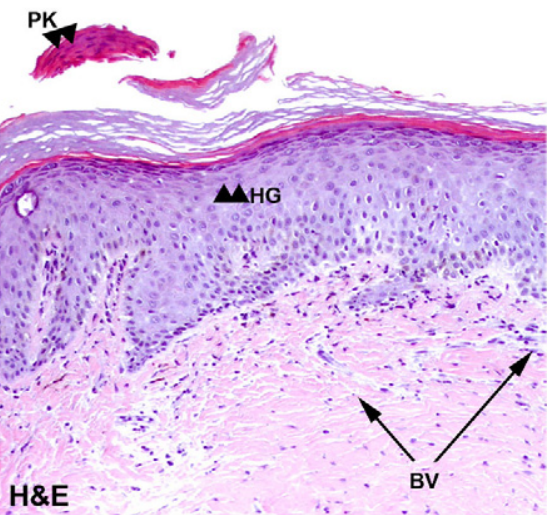

keratin 1

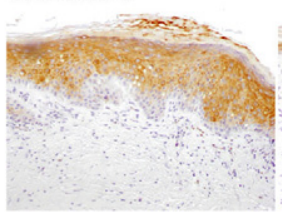

Ioricrin
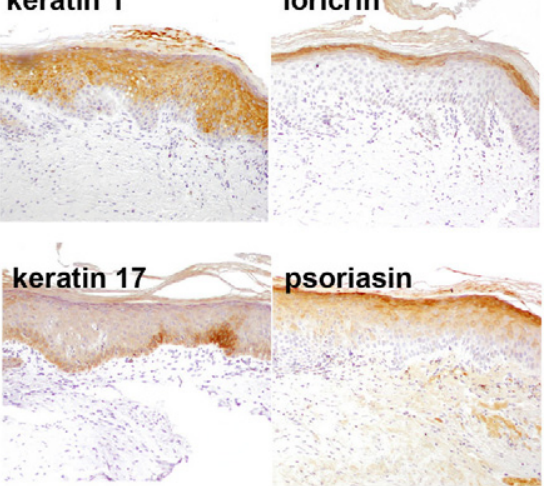

CD3- $\varepsilon$

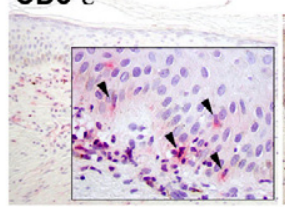

MPO

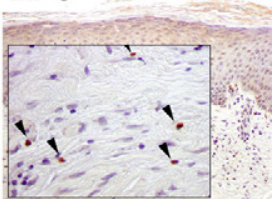

Figure 9. Histological and immunohistochemical analyses in the autologous skin-humanized mouse model. As schematized in Figure 1B, keratinocytes and fibroblasts from a psoriatic skin biopsy were used to generate skin equivalents that were grafted on nude mice. Regenerated human skin was intradermally injected with in vitro-differentiated T1 lymphocyte subpopulations derived from the same psoriatic patient in the presence of recombinant IL-22 and IL-17 cytokines and tape-stripping (TS). H\&E staining was performed on formalin-fixed paraffin-embedded sections. Focal areas of hypogranulosis (HG) and paraketosis (PK) are indicated by arrowheads, and arrows show the presence of dilated blood vessels (BV). Consecutive sections were stained for differentiation markers keratin 1 and loricrin and for proliferation markers K17 and psoriasin (hS100A7). Immunohistochemical analyses of the dermal inflammatory infiltrate were also performed in serial sections using specific antibodies anti-myeloperoxidase (MPO), to detect cells of the granulocyte series, and antiCD3- $\varepsilon$ T cell-specific antigen that indicate the localization of the injected $\mathrm{T}$ cells. Black scale bar $=100 \mu \mathrm{m}$; red scale bar $=30 \mu \mathrm{m}$. The insets show a $\times 40$ magnification. Images are representative of one psoriatic patient of three analyzed, with two to three mice per group.

\section{Discussion}

Our laboratory has previously described the skin-humanized mouse model based on the permanent engraftment of ex vivo bioengineered human skin onto the back of immunodeficient mice. ${ }^{6,7}$ After transplantation, a chimerical model is generated with a skin of human origin that is vascularized and innervated by the mouse vessels and nerves. The fibrin-based skin equivalent developed by our team presents unique characteristics and allows the generation of large bioengineered skin surfaces, which on engraftment result in a regenerated skin that retains the main anatomical and physiological features of native interfolicular human skin. In addition, the long term persistence of a healthy regenerated skin reveals the correct epidermal stem-cell preservation ${ }^{26}$ and performance even after all of the ex vivo manipulations including gene transfer. $^{6,7,27}$ Regenerated normal human skin responded effectively to stimuli such as wound healing and UV-light irradiation. ${ }^{28,29}$ We were also able to deconstruct-reconstruct several inherited skin disorders using patient derived cells. ${ }^{9,10,29,30}$ Finally, it is also important to mention that this bioengineered skin equivalent has been widely used for permanent skin regeneration in patients suffering severe skin losses. ${ }^{7,31}$

In the present study, we move another step forward by introducing in this well-characterized skin humanized mouse model specific cytokine-producing lymphocytes to model a complex skin disease, such as psoriasis, in which the immune component plays a central role.

Previous valuable psoriasis models were based on patient-derived whole human skin transplantation on immunodeficient mice. ${ }^{32-34}$ However, in addition to difficulties in sourcing, a major concern for this type of approach is the large heterogeneity of the grafting material. Conversely, the model developed in the present study is based on human skin regeneration on transplantation of a cultured bioengineered skin. This strategy enables the generation of a large number of engrafted mice with a significant and homogeneous area of single donor-derived human skin.

Using the whole skin xenotransplantation model, it has been shown that the psoriatic lesion only develops when in culture activated immunocytes (ie, general stimulus such as PHA + IL2) from patients are intradermally in- 
jected in the engrafted skin. It was proposed that the injection of such activated immune cells acts as a stimulus to drive, in turn, the activation of resident immunocytes in the xenograft. ${ }^{32,35}$ In our model, during the isolation and expansion of keratinocytes and fibroblasts, resident immune cells present in the original skin biopsy are lost. This constitutes a major difference with the whole skin transplantation model. The isolation of resident $T$ cells from skin biopsies to reintroduce them in the regenerated human skin represents an additional limiting step to inject an elevated number of animals. This problem has been circumvented by injection of in vitro derived specific $T$ cell subpopulations from peripheral blood.

We decided to study the contribution of specific $T$ cell subpopulations and/or cytokines shown before to be critical for the development of a psoriatic plaque. It has been demonstrated that a cascade of events is initiated in psoriasis that leads to the specific activation of Th1 and Th17 immune responses, with IFN-gamma and IL-22 cytokines playing a key central role in the epidermal induced changes. ${ }^{36} \mathrm{IL}-22$ has been shown to inhibit keratinocyte terminal differentiation in a three-dimensional human epidermis model. Moreover, some of the major features of psoriatic skin are also observed in the epidermis of IL-22 transgenic mice (acanthosis, loss of the granular layer and hyperkeratosis). ${ }^{37}$ IFN-gamma induced the expression of Th1-cells attracting chemokines in keratinocytes. The Th17 IL-17 cytokine has been shown to induce activation events in keratinocytes leading to the recruitment of a characteristic inflammatory infiltrate into lesional skin. ${ }^{38}$ This cytokine has been shown to induce dendritic cell (CCL20) and granulocyteattracting (CXCL1, CXCL2, CXCL5, CXCL8) chemokines. $^{37}$ In view of this complex scenario, we considered Th1 and Th17-derived cytokines as key factors to establish our novel experimental model.

In this study we also evaluated the possibility of generating a skin-humanized model of psoriasis that allows the use of skin biopsies and peripheral blood from either normal volunteers, (allogenic model) or psoriatic patients (autologous model). Because samples from healthy donors are easier to obtain, modeling the disease in an allogeneic context would yield higher number of homogeneous skin-humanized animals. Therefore, it would provide a novel platform to study the contribution of individual components (cells, cytokines, growth factors, or biochemical pathways) to the pathogenesis of the disease. In an attempt to achieve this objective, human skin was regenerated onto the back of immunodeficient mice using keratinocytes and fibroblasts from skin biopsies obtained from healthy donors. In vitro differentiated T1 cells obtained from an allogeneic healthy donor together with the Th17 recombinant IL-22 and IL-17 cytokines provided the immune component. We also applied tapestripping to provoke a barrier defect as several genetic studies have clearly demonstrated that a compromised barrier function may contribute to the progression of the disease. 23,24,39,40

Histological and immunohistochemical analyses revealed the main hallmarks of psoriasis lesions when the above mentioned combination of factors was used. A considerable hyperproliferative reaction in the epidermis was observed, with a clear induction of rete ridge elongation. In some cases, focal hypogranulosis and parakeratosis were observed. In the presence of T1 cells and both cytokines, there was a prominent inflammatory infiltrate, mainly composed of granulocytes, and CD31 staining revealed the presence of dilated capillaries in the dermis. The majority of $T$ cells present in epidermis of samples injected with $\mathrm{T} 1$ cells are of CD8 origin. However, elevated numbers of both $\mathrm{CD} 4^{+}$and $\mathrm{CD} 8^{+} \mathrm{T}$ cells were found predominantly in the dermis of allogeneic (see Supplemental Figure 3 at http://ajp.amjpathol.org) samples. To exclude the possibility of a cytotoxic reaction in the allogeneic model, the in vitro T1 differentiated subpopulation was depleted of $\mathrm{CD}^{+}$cells, and coinjected with recombinant IL-17/IL-22 cytokines in the presence of tape-stripping. In this case a similar psoriatic reaction pattern was also obtained. The same combination of factors was proven to be effective in the autologous skin-humanized mouse model, where keratinocytes, fibroblasts, and T1 subpopulations were obtained from a psoriatic patient. More importantly, the same changes associated with a psoriatic phenotype could be observed when T1 lymphocytes from unrelated healthy donors were injected in a human skin regenerated from keratinocytes and fibroblasts obtained from a skin biopsy of a psoriatic patient (data not shown). Thus, using this skinhumanized mouse model, a scenario could be envisioned in which the adequate combination of $\mathrm{T}$ cell subsets and/or cytokines interacts with an epidermal compartment with a barrier defect to develop the phenotypic changes associated to human psoriasis. In the autologous and allogenic models the T1 subpopulation and/or the combination of factors produced by these cells in conjunction with Th17-derived cytokines is critical for the acquisition of a fully developed psoriatic phenotype. This process appears to occur independently of the lymphocyte source (psoriatic patients or unrelated healthy donors). However, it has been demonstrated that many factors confer predisposition for psoriasis and might contribute not only to the genesis of the lesion but also to the severity of the disease. Among them, barrier function disturbance appears as a key factor contributing to the pathogenesis. It seems that the phenotypic conversion is more evident in certain donors/patients using this system. It would thus be relevant to undertake an exhaustive analysis to assess the genetic background of every donor/patient. This could reveal whether the system is capable of gauging differences associated with genetic background and explain differences in the phenotype observed (severity of the lesion).

The possibility of generating a humanized psoriatic model by using keratinocytes, fibroblasts, and immune cells isolated from single psoriatic patients represents a realistic opportunity to address interindividual differences in treatment efficacy.

Mature subpopulations of human lymphocytes are introduced in the system to mimic, as closely as possible, the phenotype of a completely developed human psoriatic plaque. Admittedly, within this context the model precludes the study of the initial stages of the patholog- 
ical process (ie, lymphocyte extravasation and in vivo lymphocyte differentiation). However, it emerges as a powerful tool to further characterize the established lesion and to test novel therapeutic approaches. In addition, the possibility of introducing modifications and/or combinations of components allows us to study each one of them separately. Furthermore, the use of gene modified cells (keratinocytes and fibroblasts) has been shown to be feasible..$^{9,28,30,41,42}$ Thus, generating skin-humanized mice either overexpressing or repressing specific genes will be very useful to unravel the key pathways contributing to the pathogenesis of psoriasis. In a similar fashion, lymphocyte subpopulations may also be genetically manipulated, to evaluate the cross-interacting pathways between keratinocytes and immune cells that take place in the development of the psoriatic plaque.

\section{Acknowledgments}

This article is dedicated in memory of our friend Dr. Estela Medrano whose enthusiasm and never-ending energy and passion for science will remain with us. We thank Dr. Francisco Sánchez-Madrid and Dr. Pilar Martín (Centro Nacional de Investigaciones Cardiovasculares) for their helpful discussion, and we thank Dr. Marcial García Rojo and Dr. Juan Luis Santiago (Hospital General de Ciudad Real) for their help with immunohistochemistry of inflammatory cells.

\section{References}

1. Naldi L, Gambini D: The clinical spectrum of psoriasis. Clin Dermatol 2007, 25:510-518

2. Gudjonsson JE, Johnston A, Dyson M, Valdimarsson H, Elder JT: Mouse models of psoriasis. J Invest Dermatol 2007, 127:1292-1308

3. Danilenko DM: Review paper: preclinical models of psoriasis. Vet Pathol 2008, 45:563-575

4. Wrone-Smith T, Nickoloff BJ: Dermal injection of immunocytes induces psoriasis. J Clin Invest 1996, 98:1878-1887

5. Boehncke WH, Dressel D, Zollner TM, Kaufmann R: Pulling the trigger on psoriasis. Nature 1996, 379:777

6. Del Rio M, Larcher F, Serrano F, Meana A, Munoz M, Garcia M, Munoz E, Martin C, Bernad A, Jorcano JL: A preclinical model for the analysis of genetically modified human skin in vivo. Hum Gene Ther 2002, 13:959-968

7. Llames SG, Del Rio M, Larcher F, Garcia E, Garcia M, Escamez MJ, Jorcano JL, Holguin P, Meana A: Human plasma as a dermal scaffold for the generation of a completely autologous bioengineered skin. Transplantation 2004, 77:350-355

8. Escamez MJ, Garcia M, Larcher F, Meana A, Munoz E, Jorcano JL, Del Rio M: An in vivo model of wound healing in genetically modified skin-humanized mice. J Invest Dermatol 2004, 123:1182-1191

9. Gache Y, Baldeschi C, Del Rio M, Gagnoux-Palacios L, Larcher F, Lacour JP, Meneguzzi G: Construction of skin equivalents for gene therapy of recessive dystrophic epidermolysis bullosa. Hum Gene Ther 2004, 15:921-933

10. Garcia M, Escamez MJ, Carretero M, Mirones I, Martinez-Santamaria L, Navarro M, Jorcano JL, Meana A, Del Rio M, Larcher F: Modeling normal and pathological processes through skin tissue engineering. Mol Carcinog 2007, 46:741-745

11. Schlaak JF, Buslau M, Jochum W, Hermann E, Girndt M, Gallati H, Meyer zum Buschenfelde KH, Fleischer B: T cells involved in psoriasis vulgaris belong to the Th1 subset. J Invest Dermatol 1994, 102:145-149

12. Komiyama Y, Nakae S, Matsuki T, Nambu A, Ishigame H, Kakuta S,
Sudo K, Iwakura Y: IL-17 plays an important role in the development of experimental autoimmune encephalomyelitis. J Immunol 2006, 177:566-573

13. Cua DJ, Sherlock J, Chen Y, Murphy CA, Joyce B, Seymour B, Lucian L, To W, Kwan S, Churakova T, Zurawski S, Wiekowski M, Lira SA, Gorman D, Kastelein RA, Sedgwick JD: Interleukin-23 rather than interleukin-12 is the critical cytokine for autoimmune inflammation of the brain. Nature 2003, 421:744-748

14. Nakae S, Nambu A, Sudo K, Iwakura Y: Suppression of immune induction of collagen-induced arthritis in IL-17-deficient mice. J Immunol 2003, 171:6173-6177

15. Murphy CA, Langrish CL, Chen Y, Blumenschein W, McClanahan T, Kastelein RA, Sedgwick JD, Cua DJ: Divergent pro- and antiinflammatory roles for IL-23 and IL-12 in joint autoimmune inflammation. J Exp Med 2003, 198:1951-1957

16. Austin LM, Ozawa M, Kikuchi T, Walters IB, Krueger JG: The majority of epidermal T cells in Psoriasis vulgaris lesions can produce type 1 cytokines, interferon-gamma, interleukin-2, and tumor necrosis factor-alpha, defining TC1 (cytotoxic T lymphocyte) and TH1 effector populations: a type 1 differentiation bias is also measured in circulating blood T cells in psoriatic patients. J Invest Dermatol 1999, 113:752-759

17. Wolk K, Witte E, Wallace E, Docke WD, Kunz S, Asadullah K, Volk HD, Sterry W, Sabat R: IL-22 regulates the expression of genes responsible for antimicrobial defense, cellular differentiation, and mobility in keratinocytes: a potential role in psoriasis. Eur J Immunol 2006, 36:1309-1323

18. Blauvelt A: T-helper 17 cells in psoriatic plaques and additional genetic links between IL-23 and psoriasis. J Invest Dermatol 2008 , 128:1064-1067

19. Lowes MA, Bowcock AM, Krueger JG: Pathogenesis and therapy of psoriasis. Nature 2007, 445:866-873

20. Nickoloff BJ, Xin H, Nestle FO, Qin JZ: The cytokine and chemokine network in psoriasis. Clin Dermatol 2007, 25:568-573

21. Sano S, Chan KS, Carbajal S, Clifford J, Peavey M, Kiguchi K, Itami S, Nickoloff BJ, DiGiovanni J: Stat3 links activated keratinocytes and immunocytes required for development of psoriasis in a novel transgenic mouse model. Nat Med 2005, 11:43-49

22. Zenz R, Eferl R, Kenner L, Florin L, Hummerich L, Mehic D, Scheuch $\mathrm{H}$, Angel P, Tschachler E, Wagner EF: Psoriasis-like skin disease and arthritis caused by inducible epidermal deletion of Jun proteins. Nature 2005, 437:369-375

23. Zhang XJ, Huang W, Yang S, Sun LD, Zhang FY, Zhu QX, Zhang FR, Zhang C, Du WH, Pu XM, Li H, Xiao FL, Wang ZX, Cui Y, Hao F, Zheng J, Yang XQ, Cheng $\mathrm{H}$, He CD, Liu XM, Xu LM, Zheng HF, Zhang SM, Zhang JZ, Wang HY, Cheng YL, Ji BH, Fang QY, Li YZ, Zhou FS, Han JW, Quan C, Chen B, Liu JL, Lin D, Fan L, Zhang AP, Liu SX, Yang CJ, Wang PG, Zhou WM, Lin GS, Wu WD, Fan X, Gao M, Yang BQ, Lu WS, Zhang Z, Zhu KJ, Shen SK, Li M, Zhang XY, Cao TT, Ren W, Zhang $X$, He J, Tang XF, Lu S, Yang JQ, Zhang L, Wang DN, Yuan F, Yin XY, Huang HJ, Wang HF, Lin XY, Liu JJ: Psoriasis genome-wide association study identifies susceptibility variants within LCE gene cluster at 1q21. Nat Genet 2009, 41:205-210

24. de Cid R, Riveira-Munoz E, Zeeuwen PL, Robarge J, Liao W, Dannhauser EN, Giardina E, Stuart PE, Nair R, Helms C, Escaramis G, Ballana E, Martin-Ezquerra G, den Heijer M, Kamsteeg M, Joosten I, Eichler EE, Lazaro C, Pujol RM, Armengol L, Abecasis G, Elder JT, Novelli G, Armour JA, Kwok PY, Bowcock A, Schalkwijk J, Estivill X: Deletion of the late cornified envelope LCE3B and LCE3C genes as a susceptibility factor for psoriasis. Nat Genet 2009, 41:211-215

25. Ahn SK, Hwang SM, Jiang SJ, Choi EH, Lee SH: The changes of epidermal calcium gradient and transitional cells after prolonged occlusion following tape stripping in the murine epidermis. J Invest Dermatol 1999, 113:189-195

26. Meana A, Iglesias J, Del Rio M, Larcher F, Madrigal B, Fresno MF, Martin C, San Roman F, Tevar F: Large surface of cultured human epithelium obtained on a dermal matrix based on live fibroblastcontaining fibrin gels. Burns 1998, 24:621-630

27. Serrano F, Del Rio M, Larcher F, Garcia M, Munoz E, Escamez MJ Munoz M, Meana A, Bernad A, Jorcano JL: A comparison of targeting performance of oncoretroviral versus lentiviral vectors on human keratinocytes. Hum Gene Ther 2003, 14:1579-1585

28. Escamez MJ, Carretero M, Garcia M, Martinez-Santamaria L, Mirones I, Duarte B, Holguin A, Garcia E, Garcia V, Meana A, Jorcano JL, 
Larcher F, Del Rio M: Assessment of optimal virus-mediated growth factor gene delivery for human cutaneous wound healing enhancement. J Invest Dermatol 2008, 128:1565-1575

29. García M, Llames S, García E, Meana A, Cuadrado N, Recasens M, Puig S, Nagore E, Illera N, Jorcano JL, Del Rio M, Larcher F: In vivo assessment of acute UVB responses in normal and xeroderma pigmentosum (XP-C) skin-humanized mouse models. Am J Pathol 2010, 177: 865-872

30. Di Nunzio F, Maruggi G, Ferrari S, Di lorio E, Poletti V, Garcia M, Del Rio M, De Luca M, Larcher F, Pellegrini G, Mavilio F: Correction of laminin- 5 deficiency in human epidermal stem cells by transcriptionally targeted lentiviral vectors. Mol Ther 2008, 16:1977-1985

31. Llames S, Garcia E, Garcia V, del Rio M, Larcher F, Jorcano JL, Lopez E, Holguin P, Miralles F, Otero J, Meana A: Clinical results of an autologous engineered skin. Cell Tissue Bank 2006, 7:47-53

32. Nickoloff BJ, Wrone-Smith T: Injection of pre-psoriatic skin with CD4+ T cells induces psoriasis. Am J Pathol 1999, 155:145-158

33. Nickoloff BJ, Kunkel SL, Burdick M, Strieter RM: Severe combined immunodeficiency mouse and human psoriatic skin chimeras. Validation of a new animal model. Am J Pathol 1995, 146:580-588

34. Gilhar A, David M, Ullmann Y, Berkutski T, Kalish RS: T-lymphocyte dependence of psoriatic pathology in human psoriatic skin grafted to SCID mice. J Invest Dermatol 1997, 109:283-288

35. Boyman O, Hefti HP, Conrad C, Nickoloff BJ, Suter M, Nestle FO: Spontaneous development of psoriasis in a new animal model shows an essential role for resident T cells and tumor necrosis factor-alpha. J Exp Med 2004, 199:731-736

36. Albanesi C, De Pita O, Girolomoni G: Resident skin cells in psoriasis: a special look at the pathogenetic functions of keratinocytes. Clin Dermatol 2007, 25:581-588
37. Wolk K, Haugen HS, Xu W, Witte E, Waggie K, Anderson M, Vom Baur E, Witte K, Warszawska K, Philipp S, Johnson-Leger C, Volk HD, Sterry W, Sabat R: IL-22 and IL-20 are key mediators of the epidermal alterations in psoriasis while IL-17 and IFN-gamma are not. J Mol Med 2009, 87:523-536

38. Nograles KE, Zaba LC, Guttman-Yassky E, Fuentes-Duculan J, SuarezFarinas M, Cardinale I, Khatcherian A, Gonzalez J, Pierson KC, White TR, Pensabene C, Coats I, Novitskaya I, Lowes MA, Krueger JG: Th17 cytokines interleukin (IL)-17 and IL-22 modulate distinct inflammatory and keratinocyte-response pathways. Br J Dermatol 2008, 159:1092-1102

39. Capon F, Semprini S, Chimenti S, Fabrizi G, Zambruno G, Murgia S, Carcassi C, Fazio M, Mingarelli R, Dallapiccola B, Novelli G: Fine mapping of the PSORS4 psoriasis susceptibility region on chromosome 1q21. J Invest Dermatol 2001, 116:728-730

40. Chen H, Toh TK, Szeverenyi I, Ong RT, Theng CT, McLean WH, Seielstad M, Lane EB: Association of skin barrier genes within the PSORS4 locus is enriched in Singaporean Chinese with early-onset psoriasis. J Invest Dermatol 2009, 129:606-614

41. Rio MD, Larcher F, Meana A, Segovia J, Alvarez A, Jorcano J: Nonviral transfer of genes to pig primary keratinocytes: induction of angiogenesis by composite grafts of modified keratinocytes overexpressing VEGF driven by a keratin promoter. Gene Ther 1999, 6:1734-1741

42. Larcher F, Del Rio M, Serrano F, Segovia JC, Ramirez A, Meana A, Page A, Abad JL, Gonzalez MA, Bueren J, Bernad A, Jorcano JL: A cutaneous gene therapy approach to human leptin deficiencies: correction of the murine ob/ob phenotype using leptin-targeted keratinocyte grafts. FASEB J 2001, 15:1529-1538 